\title{
ON THE COMPOSITION OF DANISH BUTTER.
}

By Harald FaBer.

(Read at the Meeting, April 4, 1900.)

THE following few remarks on the composition of Danish butter were originally intended only for use in the discussion of a paper by Mr. Estcourt on "Butter from Various Countries Compared."

Very full information of the amount of water in Danish butter is obtained by the numerous analyses made in connection with the State Butter Shows in Copenhagen (Foreign Office Report, 1889, Miscellaneous, No. 151). Table I., showing the amount of water found by the analysis of about 12,000 samples during nine years, calls for very few remarks. The average is about 14 per cent., most samples having from 13 to 15 per cent., and very few less than 12 per cent., or more than 16 per cent.

\section{TABLE I.}

Amount of Water in Danish Butter.

According to analyses of samples at the State Butter Shows.

\section{Yearly Averages.}

$\begin{array}{ccccc} & & & \text { Number of Samples. } & \text { Percentage of Water. } \\ 1890-94 & \ldots & \ldots & 4,458 & 14 \cdot 32 \\ 1895 & \ldots & \ldots & 1,517 & 13 \cdot 70 \\ 1896 & \ldots & \ldots & 1,992 & 13 \cdot 68 \\ 1897 & \ldots & \ldots & 2,016 & 13 \cdot 79 \\ 1898 & \ldots & \ldots & 2,110 & 13 \cdot 93\end{array}$


Samples grouped according to Amount of Water.

\begin{tabular}{cccccc}
$\begin{array}{c}\text { Percentage } \\
\text { of Water. }\end{array}$ & & & \multicolumn{2}{c}{$\begin{array}{c}\text { Number of Samples as Percentage } \\
\text { of Total Number. }\end{array}$} \\
& & & & $189 \cdot$ & 1898. \\
$10-11$ & $\ldots$ & $\ldots$ & $\ldots$ & $0 \cdot 8$ & $0 \cdot 4$ \\
$11-12$ & $\ldots$ & $\ldots$ & $\ldots$ & $4 \cdot 9$ & $2 \cdot 4$ \\
$12-13$ & $\ldots$ & $\ldots$ & $\ldots$ & $17 \cdot 1$ & $12 \cdot 6$ \\
$13-14$ & $\ldots$ & $\ldots$ & $\ldots$ & $37 \cdot 4$ & $37 \cdot 0$ \\
$14-15$ & $\ldots$ & $\ldots$ & $\ldots$ & $29 \cdot 7$ & $35 \cdot 3$ \\
$15-16$ & $\ldots$ & $\ldots$ & $\ldots$ & $8 \cdot 5$ & $10 \cdot 3$ \\
$16-17$ & $\ldots$ & $\ldots$ & $\ldots$ & $1 \cdot 2$ & $1 \cdot 7$ \\
$17-18$ & $\ldots$ & $\ldots$ & $\ldots$ & $0 \cdot 4$ & $0 \cdot 3$
\end{tabular}

The Customs have for some years taken samples of butter on landing. Duplicates of the samples of butter from Denmark have been analysed by Professor Stein at Copenhagen. From his reports I have compiled the following table (Table II.), showing monthly averages for the years 1898 and 1899 of the Reichert-Wollny figure, the refraction and also the number of samples which responded to the Becchi test. The refraction is by Zeiss's refractometer at $45^{\circ} \mathrm{C}$.

The chemical composition of the butter-fat as expressed, for instance, by the Reichert-Wollny figure varies with the season, the time since calving, and the treatment generally of the cows. In Denmark cows are generally housed from the middle of October to the middle of May, and the calving takes place in autumn and winter. Correspondingly, we find the Reichert-Wollny figure higher in the winter and spring than in summer, and lowest in the autumn, the maxima (32.6 and 32.5) for the two years occurring in March, the minima (24.3 and 25.6) in October. The effect of moving the cows from cold fields to warm byres in October, additional to the increased number of new-calved cows, finds its expression in a rapid rise in the Reichert-Wollny figure from October to November.

It has at last been recognised, also by the chemists of the Government Laboratory, that the feeding of cotton-cake imparts something to the butter which reacts to the Becchi test, and that, consequently, a cotton-oil reaction does not necessarily imply an addition of margarine. The comparison of the number of samples for the two years which gave the Becchi reaction is interesting. In 1898, which was remarkable for a luxurious growth of grass, the cows were grass-fed all through the summer, and from June to October inclusive not one sample exhibited the reaction, as no cotton-cake was used, while several samples reacted during the time the cows were stall-fed. The year 1899 was quite different; a cold and dry spring and a dry and hot summer affected the growth of grass so unfavourably that the cows had to have some additional food nearly all through the summer, and as cotton was the cheapest cake, and Russian sunflower cake (which is otherwise very much used) difficult to get, large quantities of cotton-cake were used, with the result that every fourth sample gave the Becchi reaction in summer-time, and six out of every seven responded to the test during the months of November and December. 
TABLE II.

Statement showing Variation in Chemical Composition of Danish Butter.* The samples analysed are duplicates of those taken by Her Majesty's Customs at port of importation.

1898.

\begin{tabular}{|c|c|c|c|c|c|c|}
\hline \multicolumn{2}{|l|}{ Month. } & $\begin{array}{l}\text { Number of } \\
\text { Samples. }\end{array}$ & $\begin{array}{l}\text { Reichert-Wollny } \\
\text { Figure. }\end{array}$ & $\begin{array}{l}\text { Refraction. } \\
\text { Zeiss at } 45^{\circ} \mathrm{C} .\end{array}$ & Becchi Test. & $\begin{array}{l}\text { R.-W. } \\
\text { Max. and Min. }\end{array}$ \\
\hline January & $\ldots$ & None & - & - & - & \multirow{7}{*}{ Max. $32 \cdot 6$} \\
\hline February & $\ldots$ & 7 & $30 \cdot 7$ & $40 \cdot 4$ & 4 & \\
\hline March & $\ldots$ & 16 & $30 \cdot 2$ & $40 \cdot 0$ & 10 & \\
\hline April & $\ldots$ & None & - & - & - & \\
\hline May ... & $\ldots$ & 14 & $30 \cdot 1$ & 40.5 & 9 & \\
\hline June ... & .. & 3 & $30 \cdot 2$ & $40 \cdot 7$ & - & \\
\hline July ... & $\ldots$ & None & - & - &, & \\
\hline August & $\ldots$ & 7 & $29 \cdot 1$ & $41 \cdot 8$ & ," & \\
\hline September & $\ldots$ & 16 & $28 \cdot 4$ & $42 \cdot 5$ & ," & \\
\hline October & $\ldots$ & 6 & $26 \cdot 4$ & $42 \cdot 7$ & ," & Min. $24 \cdot 3$ \\
\hline November & $\ldots$ & 16 & $29 \cdot 5$ & 40.5 & 5 & $(\operatorname{Max} .31 \cdot 7)$ \\
\hline December & $\ldots$ & (2) & $(30 \cdot 0)$ & $(39 \cdot 4)$ & $(1 ?)$ & \\
\hline
\end{tabular}

1899.

\begin{tabular}{ll|c|c|c|c|c}
\hline January & $\ldots$ & None & - & - & - & \\
February & $\ldots$ & 8 & $30 \cdot 7$ & $40 \cdot 0$ & 7 & \\
March & $\ldots$ & 17 & $30 \cdot 8$ & $40 \cdot 4$ & 14 & Max. 32.5 \\
April ... & $\ldots$ & $(2)$ & $(28 \cdot 3)$ & $(41 \cdot 5)$ & (None) & \\
May ... & $\ldots$ & 22 & $29 \cdot 3$ & $40 \cdot 7$ & 14 & \\
June .. & $\ldots$ & $(2)$ & $(30 \cdot 5)$ & $(40 \cdot 6)$ & $(1)$ & \\
July ... & $\ldots$ & None & - & - & -1 & \\
August & $\ldots$ & 9 & $28 \cdot 1$ & $41 \cdot 6$ & 1 & \\
September & $\ldots$ & 13 & $26 \cdot 9$ & $41 \cdot 8$ & 3 & Min. 25.6 \\
October & $\ldots$ & 3 & $27 \cdot 9$ & $41 \cdot 2$ & 2 & (Max. 31.8) \\
November & $\ldots$ & 18 & $30 \cdot 8$ & $39 \cdot 9$ & 15 & \\
December & $\ldots$ & 3 & $30 \cdot 5$ & $40 \cdot 0$ & 3 & \\
\hline
\end{tabular}

Percentage of Number of Samples which reacted by the Becchi Test.

$\begin{array}{lcccc} & & & 1898 . & 1899 . \\ \text { January to May } & \ldots & \ldots & 62 & 71 \\ \text { June to October } & \ldots & \ldots & 0 & 26 \\ \text { November to December } & \ldots & 33 & 86\end{array}$

* The figures included in brackets refer to samples which were so small that it was not deemed advisable to include them in the percentage table. 